\title{
Determination of the Dose of Erythrosine B as a Preparation for Inducing the Experimental Rats to Be Spastic
}

\author{
Marina Indriasari ${ }^{1}$, Hardinsyah $^{1}$, Lilik Kustiyah ${ }^{1}$, Bambang Pontjo Priosoeryanto ${ }^{2}$, \\ Ferial Hadipoetro Idris ${ }^{3}$ \\ ${ }^{1}$ Faculty of Human Ecology, Bogor Agricultural University, Bogor, West Java, Indonesia \\ ${ }^{2}$ Faculty of Veterinary, Bogor Agricultural University, Bogor, West Java, Indonesia \\ ${ }^{3}$ Faculty of Medicine and Health University of Muhammadiyah, Jakarta, Indonesia \\ Email: indriasarimarina@gmail.com
}

\begin{abstract}
This study aimed to make the experimental rats spastic using Erythrosine B (ErB) in the correct dose. Five male Sprague-Dawley rats (T) aged 10-12 weeks with a weight of 200-250 mg were injected with ErB and doses as follows: $20 \mathrm{mg} / \mathrm{kg}$ bw for T1, $80 \mathrm{mg} / \mathrm{kg}$ bw for T2, $160 \mathrm{mg} / \mathrm{kg}$ bw for $\mathrm{T} 3,320 \mathrm{mg} / \mathrm{kg}$ bw for T4, and $400 \mathrm{mg} / \mathrm{kg}$ bw for T5. The results of 4 -wk observation indicated that $\mathrm{T} 1$ had a rapid decrease in spasticity. T2 still experienced spasticity on day 3 with $100 \%$ muscle resistance. Its spasticity reduced by $25 \%$ within 14 days, and it still experienced spasticity with $50 \%$ muscle resistance within 28 days. T3 experienced spasticity with $100 \%$ muscle resistance until day 7 . T4 and T5 died after induction. It could be concluded that the ErB dose of $80 \mathrm{mg} / \mathrm{kg}$ bw was used as a preparation for the induction of experimental rats.
\end{abstract}

Keywords: Dose, Erythrosine B, spastic.

\section{Introduction}

Spasticity is a condition in which muscle resistance increases involuntarily, and it depends on the speed of movement. This condition may occur secondary to other diseases such as tumor, stroke, multiple sclerosis, cerebral palsy, trauma or abnormalities in the brain and spinal cord, and peripheral nerve injuries. Spasticity is accompanied by paresis and other signs, such as increased stretch reflex which is referred to as upper motor neuron syndrome. Paresis mainly affects the distal muscles characterized by the loss of ability to do movements. ${ }^{[1]}$

Upper motor neuron syndrome occurs because of the damage to the descending motor pathways at the cortical level, brain stem, or spinal cord. When an injury causes acute spasticity, muscle tone becomes flaccid with hyporeflexia before the spasticity occurs. Spasticity that occurs is related to changes in muscle tone because of the changes in the balance of input from reticulospinal tract and other descending pathways to motor units and interneuronal circuits of the spinal cord due to an absence of an intact corticospinal system. These changes cause the loss of tonic descending or phasic excitatory and inhibitory inputs to the spinal motor body, changes in the segmental balance of excitatory and inhibitory controls, denervation supersensitivity, and neuronal sprouting. Chronic spasticity causes muscle shortening, and contractures may occur due to muscle stiffness. ${ }^{[2]}$

Erythrosine B (ErB) produced by ScienceLab.com, Inc in Houston, Texas is synonymous with Acid Red 51, FD\&C\#3 C.I. Food Red 14, 3,6-Dihydroxy-2,4,5,7-tetraiodospiro[isobenzofuran-1(3HO.9$[9 \mathrm{H}]$ xanthen]-3-one disodium salt. Its chemical formula is C20H6I4Na2O5. The toxic dose for SpragueDawley rats is $1264 \mathrm{mg} / \mathrm{kg}$ body weight $(\mathrm{mg} / \mathrm{kg} \mathrm{bw})$. One of the effects of $\mathrm{ErB}$ on the body can be found in the nervous system, besides the lungs and mucous membranes. ErB is $2^{\prime}, 4^{\prime}, 5^{\prime}, 7^{\prime}-$ tetraiodofluoroescein disodium salt that is used as a red dye in some foods such as cherries and fish. Its maximum absorption in aqueous solution is $530 \mathrm{~nm}$, and it is affected by photodegradation..$^{[3]}$

The results of a study by Mekkawy et al..$^{[4]}$ indicated that ErB given in doses of 0.08 and $0.4 \mathrm{~g} / \mathrm{kg}$ bw to rats for 30 days in their diet could cause chromosome damage. In the biochemical test, a significant increase was found in total protein and nucleic acid concentrations in the rats' brains which caused mutagenic activities. ErB has a similar structure with thyroxine. Thyroxine is the main hormone 
secreted into the bloodstream by the thyroid gland that can also be made in the laboratory. Thyroxine plays a role in controlling muscle activity, brain development, and bone maintenance..$^{[5]}$

A study by Zong et al ${ }^{[6]}$ used male Sprague-Dawley rats weighing 200-240 g that were made spastic by making a lesion in the unilateral motor cortex. The ErB at a dose of $20 \mathrm{mg} / \mathrm{kg}$ bw was injected into the lateral tail vein of the experimental rats. The study was accompanied by invasive procedures; i.e., by performing surgery on the skull and partially injuring the cortex with hot rays. After obtaining ethical approval from the Institute of Research and Community Services (LPPM) of Bogor Agricultural University for our animal study, the intervention for the animals was performed with minimally invasive procedures. Therefore, the present study was conducted by using several doses of $\operatorname{ErB}$ and observing the recovery period of the experimental animals to determine the correct dose of ErB within 28 days.

\section{Methods}

\subsection{Design, Location, and Duration of the Study}

The experimental study was conducted at the Faculty of Veterinary of Bogor Agricultural University for four weeks in May 2018. The maintenance of rats, intervention, and assessment were conducted at the Faculty of Veterinary of Bogor Agricultural University. An ethical approval certificate for animal study number 92-2018/IPB was issued by the LPPM of Bogor Agricultural University.

\section{2 Materials and Tools}

The main materials used to make the experimental rats spastic were ErB powder (C.I.45430) made in Japan (CAS Number: 15423580) and distilled water as the solvent. The ErB was obtained from PT. Cipta Bangun Nauli, Bogor. The experimental animals in the study were five male Sprague-Dawley rats aged 10-12 months with a weight of 200-250 g. The rats were obtained from Biopharmaca Research Center of Bogor Agricultural University. The rats received a health certificate for laboratory animals from the animal hospital of Bogor Agricultural University. The tools used were 1-ml syringe, mortar and pestle, digital animal scales, and stainless steel stirring rods. The standard diet fed was made at PT. Indofeed in Bogor. The composition of the standard diet is presented in Table 1. A standard cage was used for each rat.

Table 1. Composition of the standard diet for experimental rats.

\begin{tabular}{cc}
\hline Composition & Percentage \\
\hline Water content & 12 \\
Carbohydrates & 30 \\
Protein & 23 \\
Fat & 4 \\
Crude fiber & 5 \\
Ash & 8 \\
Ca & 1 \\
Other vitamins and minerals & 17 \\
\hline
\end{tabular}

Source: PT. Indofeed, Bogor

Material preparation. ErB powder was weighed and calculated into five doses (i.e., $4 \mathrm{mg}, 20 \mathrm{mg}, 40$ $\mathrm{mg}, 90 \mathrm{mg}$, and $100 \mathrm{mg})$. These doses were determined from the minimal dose $(20 \mathrm{mg} / \mathrm{kg} \mathrm{bw})$ according to the study by Zong et al. ${ }^{[6]}$ to the maximum dose $(0.4 \mathrm{~g} / \mathrm{kg} \mathrm{bw})$ which was a toxic dose. ${ }^{[6]}$ Each ErB powder was dissolved with distilled water until it became $1 \mathrm{~mL}$.

Sample size determination. The sample size used was based on the WHO's sample criteria; i.e., at least five animals (WHO 2000). ${ }^{[7]}$ This study used one rat for each group and each dose. 
Maintenance of experimental animals. The rats aged 10-12 months were adapted for seven days in advance. The rats' weight was weighed before and after the adaptation. During adaptation, the experimental rats were fed $20 \mathrm{~g}$ of the standard diet a day, and they drank ad libitum.

Intervention on the experimental rats. After the adaptation period, the five rats were warmed in a tube at $\pm 30^{\circ} \mathrm{C}$. The rats were then restrained. The Erb solution $(1 \mathrm{~mL})$ was injected through the lateral tail vein. The 4-wk observation was conducted to assess spasticity on days 7, 14, 21, and 28.

Assessment of the experimental rats. All the rats' skins, eye membranes, body fluid, and feces appeared pink immediately after induction. The spasticity was determined by examining all four limbs during passive flexion and extension movements. Muscle resistance would be found if there was spasticity. The results of spasticity assessment were expressed as the percentage of resistance in which $100 \%$ was the strongest resistance, and 0\% was without resistance (normal). The muscle resistance occurred in the lowest spasticity was $25 \%$.

\section{Results}

The doses of ErB given to the experimental rats were determined based on their body weight after the adaptation period. These doses were calculated based on the safety of their use for the survival of experimental rats. Table 2 shows the ErB doses used for each experimental rat.

Table 2. ErB doses for the experimental rats.

\begin{tabular}{ccc}
\hline Experimental rats & ErB doses $(\mathrm{mg} / \mathrm{kg} \mathrm{bw})$ & Induction doses $(\mathrm{mg} / 1 \mathrm{~mL})$ \\
\hline $\mathrm{T} 1$ & 20 & 5 \\
$\mathrm{~T} 2$ & 80 & 20 \\
$\mathrm{~T} 3$ & 160 & 40 \\
$\mathrm{~T} 4$ & 320 & 90 \\
$\mathrm{~T} 5$ & 400 & 100 \\
\hline
\end{tabular}

The minimum dose of ErB used was $20 \mathrm{mg} / \mathrm{kg}$ bw, according to a study by Zong et al. ${ }^{[6]}$ which showed that rats recovered from spasticity condition in six days with this dose. In the present study, the dose of ErB administered was increased using the following formula: ${ }^{[6]}$

$$
20 \times 2^{n}
$$

Table 3. Spasticity values of the experimental rats.

\begin{tabular}{cccccc}
\hline Experimental rats & Day 3 & Day 7 & Day 14 & Day 21 & Day 28 \\
\hline T1 & $75 \%$ & $50 \%$ & $50 \%$ & $25 \%$ & $25 \%$ \\
T2 & $100 \%$ & $75 \%$ & $75 \%$ & $50 \%$ & $50 \%$ \\
T3 & $100 \%$ & $100 \%$ & $75 \%$ & $75 \%$ & $50 \%$ \\
T4 & \multicolumn{5}{c}{ Died on day 2 after induction } \\
T5 & Died shortly after induction \\
\hline
\end{tabular}

Table 3 shows the 28-d observation results of spasticity value. The results of the study showed that T1 -- the experimental rat receiving $20 \mathrm{mg} / \mathrm{kg}$ bw of ErB -- had a rapid decrease in spasticity. T1's muscle resistance decreased by $25 \%$ in three days. T2 -- the experimental rat receiving $80 \mathrm{mg} / \mathrm{kg}$ bw of ErB -- still experienced spasticity on day 3 with $100 \%$ muscle resistance. The spasticity in T2 reduced by $25 \%$ within 14 days, and it still experienced spasticity with $50 \%$ muscle resistance within 28 days. T3 -- the experimental rat receiving $160 \mathrm{mg} / \mathrm{kg}$ bw of ErB -- experienced spasticity with $100 \%$ muscle resistance for a long time (until day 7). T4 -- the experimental rat receiving $320 \mathrm{mg} / \mathrm{kg} \mathrm{bw}$ of ErB -died on day 2 after induction. T5 -- the experimental rat receiving $400 \mathrm{mg} / \mathrm{kg}$ bw of ErB -- died shortly after induction. Table 3 concludes that the experimental rat receiving a dose of $80 \mathrm{mg} / \mathrm{kg}$ bw shows a 
tendency to maintain the spasticity condition for a long time; i.e., spasticity with muscle resistance of $75 \%$ for 14 days and $50 \%$ for 14 days.

The results of this study was in line with a study by Zong et al. ${ }^{[6]}$ who found the significant decrease after 16-wk observation in the values of the footprint analysis for foot spread due to spastic conditions in the limbs of male Sprague-Dawley rats weighing 200-240 g after receiving $20 \mathrm{mg} / \mathrm{kg} \mathrm{bw}$ of ErB induction without head surgery. The limb disability due to acquired brain lesions disrupted the descending pathways. One of the disruptions was the occurrence of spasticity. ${ }^{[8]}$ The spasticity made in the previous study would recover after 16 weeks because of the contralateral transfer of nerve branches. The contralateral transfer allowed the contribution of stimulation from interconnected nerve branches. Contralateral nerve fibers would innervate the spastic muscles, which supported the active control of the impaired limbs from the other limbs that were healthy. ${ }^{[6]}$

\section{Conclusion}

The dose of ErB which was administered as a preparation for the induction of experimental rats to obtain a longer spastic condition was $80 \mathrm{mg} / \mathrm{kg}$ bw.

\section{References}

1. G. Bavikatte and T. Gaber, "Approach to spasticity in general practice," British Journal of Medical Practitioners, vol. 2, no. 3, pp. 29-34, 2009.

2. A. Kheder and K. P. Nair, "Spasticity: pathophysiology, evaluation and management," Pract Neurol, vol. 12, no. 5, pp. 289-298, 2012.

3. Gurr and Edward, "Synthetic Dyes in Biology, Medicine and Chemistry," Elsevier, 2012, pp. 197- 198,.

4. H. A. Mekkawy, A. A. Massoud, and A. M. El-Zawahry, "Mutagenic effects of the food color erythrocine in rats," Probl Forensic SCI, vol. 43, pp. 184-191, 2000.

5. M. Dratman and J. Gordon, "Thyroid hormones as neurotransmitters," Thyroid, vol. 6, no. 6, pp. 639-47, 1996.

6. H. Zong, F. Ma, L. Zhang, H. Lu, J. Gong, M. Cai, H. Lin, Y. Zhu, and C. Hou, "Hindlimb spasticity after unilateral motor cortex lesion in rats is reduced by contralateral nerve root transfer," Bioscience Reports, no. 36, 2016.

7. World Health Organization, " Guideline for Breeding and Care of Laboratory Animals, 2000.

8. N. H. Mayer, A. Esquenazi, and M. K. Childers, "Common patterns of clinical motor dysfunction," Muscle Nerve Suppl, vol. 6, pp. 21-35, 1997. 